\title{
Wound Healing Potential of Ipomoea carnea Jacq.: An Un-Explored Herb Used in Indian Traditional System of Medicine
}

\author{
Vellingiri Vadivel* and Pemaiah Brindha \\ Department of CARISM, School of Chemical and Biotechnology, Chemical Biology Lab (ASK II-409), SASTRA University, India
}

Submission: May 06, 2017; Published: June 19, 2017

*Corresponding author: Vellingiri Vadivel, Department of CARISM, School of Chemical and Biotechnology, SASTRA University, India;

Email: vadivel@carism.sastra.edu

\begin{abstract}
Historically, plants have provided a source of novel drug compounds as plant derived medicines have made large contributions to human health and well being. Wounds are essentially the disruption of functional continuity of cells and tissues at the site of injury, and can be caused by insults to the tissue sites by physical, chemical, microbiological or immunological process. During the last two decades, there has been increased interest to assess the utility of plant extracts in wound healing and to gain more insight into the active constituents that promote or modulate the healing process. One such Indian wound healing medicinal is I.carnea jacq., which is widely distributed throughout India and in many parts it is cultivated as hedge plant. In Indian indigenous medical practice, the leave of this plant is used to treat wounds along with oil. Research related to the wound healing property of this plant is meagre and collection of information regarding this plant might be useful to investigate the wound healing potential and therapeutic mechanism of I. carnea and also to develop a novel wound healing drug from this plant. Hence in this review, we have given the summation of literature regarding this plant.
\end{abstract}

Keywords: Ipomea carnea; Morning glory; Leaf extract; Wound healing, Indian medicine

\section{Introduction}

Wounds can be major causes of physical disabilities and may lead to losses of many productive man hours [1]. Wounds are essentially the disruption of functional continuity of cells and tissues at the site of injury, and can be caused by insults to the tissue sites by physical, chemical, microbiological or immunological process [2]. Humans and all animals have in situ capabilities of healing wounds in their body parts through continuous tissue repair and tissue regeneration [3]. However, such capabilities are impaired by age, stress situation, obesity, sex, life style, conditions of health and immunity status, severity and types of wounds, patient's medication status, disastrous nature of the assault-environment around the site of the wounds and potentials of serious microbial infection [4].

Curing of acute and chronic wounds proceed through common basic phases of hemostatis, inflammation, proliferation, fibroplasias, collagen deposition, epithelialization, contraction, re-modelling and maturation (Figure 1) [5]. During the wound healing process, a series of events encompass the repair especially through the presence and actions of activated

platelets, neutrophils and macrophages [6]. Increased vascular permeability and angiogenesis are the consequences of the healing, where multiple cellular and cytokine-mediated events are recruited [7]. The endothelial cells are up-regulated by the actions of secreted soluble factors from the activated cells which include the fibroblast growth factors, transforming growth factors, epidermal growth factors and vascular endothelial growth factors among others [8]. The platelets also get activated by the contents from the vascular wall; the main activators such as fibronectin, fibrillar collagen and other matrix proteins cause the kickoff $[9,10]$. 


\section{Global Journal of Pharmacy \& Pharmaceutical Sciences}

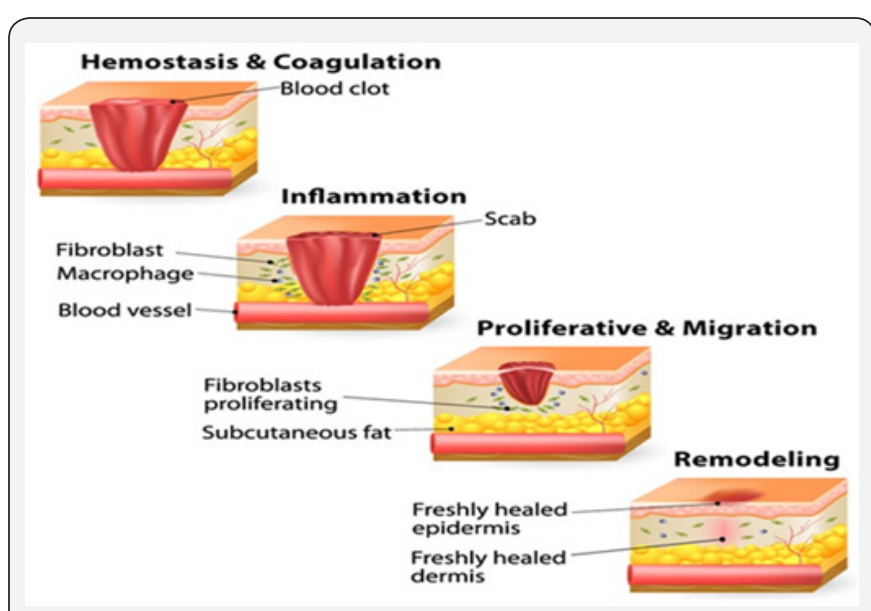

Figure 1: Different stages of wound healing process.

The basic understanding that platelets and the fibrins produced from fibrinogen at the wound site set off several biochemical processes which include collagen synthesis, cell migration, fibroplasias and angiogenesis have been significantly investigated [11]. During the last two decades, there has been increased interest to assess the utility of plant extracts in wound healing and to gain more insight into the active constituents that promote or modulate the healing process $[12,13]$. Among the various wound healing plants, I. carnea Jacq. (Family: Convolvulaceae) is well known herb extensively used in folk medicine in India.

\section{Ipomoea carnea}

I. carnea is popularly known as morning glory, a native plant of South America and is cultivated in India as hedge plant. This plant is spread all over the world including American tropics, Argentina, Brazil and Bolivia, Pakistan, Srilanka etc. In India it is distributed particularly in central and Southern states [14,15]. In India, it has become a naturalized species invading the wetlands, canals, drain banks, waste lands, field edges and road sides. The plant can propagate both asexually by stems which show rooting within a few days and sexually by seeds, and has rapid growth rate.

It is a large diffuse, straggling shrub with milky juice, grows to a height of $2 \mathrm{~m}$ on terrestrial land, but acquires a shorter height in the aquatic habitats [16]. The stem is thick and develops into a solid trunk over several years with many branches from base. The stem is erect, woody, hairy, and more or less cylindrical in shape and greenish in colour (Figure 2). The leaf is simple, alternate and petiolate and the petiole is cylindrical. The upper surface of leaf is dull green and the lower surface is paler. It has dichotomously branched axillary and terminal pedunculate cymes. Flowers are axial and pale rose/light violet in colour and the pedicel is green, erect and cylindrical. The mouth of the corolla has an entire margin, with slight conspicuous depressions at the points of the cohesion of the petals. Fruits have a glabrous capsule and seeds are silky [17].

\section{Phytochemistry}

The leaves have been recorded to contain a polysaccharide called Ipomose and saponins. Chemical analysis of showed the water solubility (8.43-12.60\%), lignin content (18.08\%), holocellulose content (67.49\%), cellulose content (22.40\%) and ash content (6.14\%) [18]. Presence of phenols, flavonoids, alkaloids, tannins, glycosides and Dibutyl Phthalate [19-24]. Presence of swainsonine and calystegines (Figure 2) were detected in the aqueous ethanolic extract of leaf $[25,26]$. Leaves showed the presence of thirteen compounds which include hexadecanoic acid, stearic acid, 1,2-diethyl phthalate, n-octadecanol, octacosane, hexatriacontane, tetracontane, 3-diethylamino-1-propanol and stigmasterol [27-29]. Latex of $I$. carnea was reported to contain a serine protease called carnein [30].

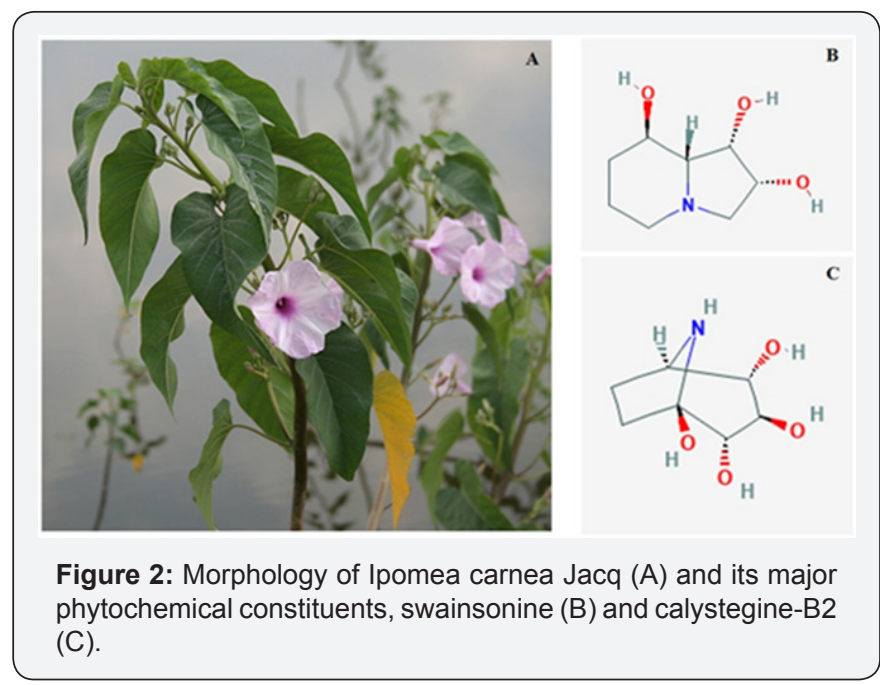

\section{Medicinal value}

Carnea has been used traditionally for the treatment of a large number of diseases. Leaves are used as purgative and leaves paste is applied on sore between toes and fingers due to fungal infection [31].The milky juice of plant has been used for the treatment of leucoderma and other related skin diseases [27]. The whole plant extract prepared in hot water is extensively used as an anti-rheumatic medicine, and the plant is also believed to reduce the teratogenic effect of cyclo-phosphamide [32]. In Africa, leaves of related species I. involucrata are claimed to be effective in the treatment of pile, rheumatic pain, toothache and other inflammatory conditions [33]. This plant was reported to possesses many medicinal properties like anti-inflammatory activity [34], antioxidant activity [35,36], anti-diabetic activity [37], muscle strain relieving activity [38], anti-bacterial activity [39], anti-fungal activity [40], cardio-vascular activity [41], immuno-modulatory activity [42], anxiolytic activity [43], and hepato-protective activity [44].

Flower extract of I. carnea was found to have protective effect on hematological changes occurring toluene di-isocyanateinduced inflammation in Wistar rats. Leaves of $I$. carnea are used 
in the treatment of wounds along with sesame/coconut oil by the traditional healers in India. According to indigenous system of medicine in Tamilnadu, the wounds are treated by applying oil and then dressed with the leaves of I. carnea. Would healing activity of I. carnea flower extract containing kaempferol was proven in animal model by Ambiga et al. [45]. Methanolic extract of I. carnea was found to possess significant would healing property [46]. Tubers of related species (I. batatas) was also reported to exhibit would healing activity [47].

\section{Toxicity issues}

Toxic and poisoning effects of I. carnea leaf was reported by Sharma and Bachheti [48] and also experimentally proven by Amna et al. [49]. I. carnea [50] and its related plants I. sericophylla and I. riedelii [51] were reported to be toxic to cattle and affected the central nervous system. Aqueous extract of this plant exhibited embryo toxicity in rat model $[52,53]$. The role of alkaloids in the toxicity of $I$. carnea was experimentally proved by Hueza et al. [54]. Toxicity of I. carnea was proven in rat [55], guinea pig [56,57] and goat models [58].

\section{Conclusion}

Nature has given herbals as a gift to the human beings for living a healthy life. But, some of the herbal plants are underutilized or un-explored to the extent that they actually deserve to treat human ailments. It is the responsibility of the researchers to reveal the therapeutic efficacy of medicinal plants, which are used by ethnic populations as well as by indigenous medical practitioners. I.carnea is a wonderful wound healing herb used in Indian indigenous system of medicine along with sesame/ coconut oil, but the detailed scientific research on its therapeutic potential is not yet carried out and also the mechanism of wound healing action was not investigated scientifically. Hence, necessary steps could be taken to evaluate the medicinal value of this plant and also to clarify the toxicity issues associated with this herb. Since, the plant parts of I. carnea are reported as toxic in various in-vivo models, it has been used only for external applications in wound healing. But, dermal/skin toxicity of this plant extract/active constituents should also be analyzed in suitable experimental models. Research initiatives on this plant could provide a novel, safe and efficient wound healing drug to human community.

\section{Acknowledgement}

Authors are thankful to the Honourable Vice Chancellor of SASTRA University, Thanjavur, Tamilnadu, India for his constant encouragement and support to prepare this review work.

\section{References}

1. Li J, Chen J, Kirsner R (2007) Pathophysiology of acute wound healing Clin Dermatol 25(1): 9-18.

2. Anitua E, Andia I, Ardanza B, Nurden P, Nurden AT (2004) Autologus platelets as a source of proteins for healing and tissue regeneration. Thromb Haemost 91(1): 4-15.
3. Borzini P, Mazzucco I (2007) Platelet-rich plasma (PRP) and platelet derivatives for topical therapy. What is true from the biologic view point? ISBT Science Series 2(1): 272-281.

4. Guo S, DiPietro LA (2010) Factors affecting wound healing. J Dent Res 89(3): 219-229.

5. Beck LS, DeGuzman L, Lee WP, Xu Y, Siegel MW, et al. (1993) One systematic administration of transforming growth factor Beta1 reverses age or glucocorticoid-impared wound healing. J Clin Invest 92(6): 2841-2849.

6. Frank S, Hubner G, Breier G, Longaker MT, Greenhalgh DG, et al. (1995) Regulation of vascular endothelial growth factor expression in cultured keratinocytes: Implication for normal and impaired wound healing. J Biol Chem 270(21): 12607-12613.

7. Frank S, Madlener M, Werner S (1996) Transforming growth factors beta1, beta2, and beta 3 and their receptors are differentially regulated during normal and impaired wound healing. J Biol Chem 271(17): 10188-10193.

8. Palu A, Su C, Zhou BN, West B, Jensen J (2010) Wound healing effects of noni (Morinda citrifolia L.) leaves: A mechanism involving its PDGF/A2A receptor ligand binding and promotion of wound closure. Phytother Res 24(10): 1437-1441.

9. Darby IA, Hewitson TD (2007) Fibroblast differentiation in wound healing and fibrosis. Int Rev Cytol 257: 143-179.

10. Iyu D, Juttner M, Glen JR, White AE, Johnson AJ, et al. (2011) PGE1 and PGE2 modify platelet function through different prostanoid receptors. Prostaglandins Other Lipid Mediat 94(1-2): 9-16.

11. Riccioti E, Fitzgerlad GA (2011) Prostaglandins and inflammation. Arterioscler Thromb Vasc Biol 31 (5): 986-1000.

12. Kumar B, Vijayakumar M, Govindarajan R, Pushpangadan P (2007) Ethnopharmacological approaches to wound healing - Exploring medicinal plants of India. J Ethnopharmacol 114(2): 103-113.

13. Ghosh PK, Gaba A (2013) Phyto-extracts in wound healing. J Pharm Pharm Sci 16(5): 760-820.

14. Chaudhuri H, Ramaprabhu T, Ramachandran V (1994) Ipomoea carnea Jacq: A new aquatic weed problem in India. J Aquat Plant Manage 32: 37-38.

15. Ekka NR, Dixit VK (2007) Ethno-Pharmacognostical studies of medicinal plants of Jashpur district (Chattisgarh). IJGP 1(1): 2-4.

16. Rout GR, Senapati SK, Aparajita S (2010) Identification and phylogenetic analysis of Ipomoea species collected from Eastern India using inter simple sequence repeat markers. International Journal of Pharma and Bio Sciences 1(4): 1-13.

17. Fatima N, Rahman MM, Khan MA, Fu J (2014) A review on Ipomoea carnea: Pharmacology, toxicology and phytochemistry. J Complement Integr Med 11(2): 55-62.

18. Nandkumar P (2011) Comparative study between soda lignin and soda anthraquinone lignin in terms of physiochemical properties of Ipomoea carnea. International Journal of Chemical, Environmental and Pharmaceutical Research 2(1): 26-29.

19. Tirkey K, Yadava RP, Mandal TK, Banerjee NC (1988) Pharmacological study of Ipomoea carnea. Indian Veterinary Journal 65(3): 206-210.

20. Sahayaraj K, Ravi C (2008) Preliminary phytochemistry of Ipomea carnea Jacq. and Vitex negundo Linn. leaves. Int J Chem Sci 6(1): 1-6.

21. Khatiwora E, Adsul VB, Kulkarni MM, Deshpande NR, Kashalkar RV (2010) Spectroscopic determination of total phenol and flavonoid contents of Ipomoea carnea. International Journal of ChemTech Research 2(3): 1698-1701. 


\section{Global Journal of Pharmacy \& Pharmaceutical Sciences}

22. Adsul V, Khatiwora E, Kale A, Deshpande N (2011) HPTLC as a standardization tool: Dibutyl phthalate isolated from Ipomoea carnea leaves. Journal of Pharmacy Research 4(7): 2239-2240.

23. Khatiwora E, Adsul VB, Kulkarni M, Deshpande NR, Kashalkar RV (2012) Antibacterial activity of Dibutyl Phthalate: A secondary metabolite isolated from Ipomoea carnea stem. Journal of Pharmacy Research 5(1): 150-152.

24. Sahayaraj K, Kombiah P, Dikshit AK, Rathi JM (2015) Chemical constituents of the essential oils of Tephrosia purpurea and Ipomoea carnea and their repellent activity against Odoiporus longicollis. Journal of the Serbian Chemical Society 80(4): 465-473.

25. De Balogh KK, Dimande AP, van der Lugt JJ, Molyneux RJ, Naudé TW, et al. (1999) A lysosomal storage disease induced by Ipomoea carnea in goats in Mozambique. J Vet Diagn Invest 11(3): 266-273.

26. Cook D, Oliveira CA, Gardner DR, Pfister JA, Riet-Correa G, et al. (2015) Changes in swainsonine, calystegine, and nitrogen concentrations on an annual basis in Ipomoea carnea. Toxicon 95: 62-66.

27. Adsul V, Khatiwora E, Kulkarni M, Tambe A, Pawar P, et al. (2009) GCMS study of fatty acid, esters, alcohols from the leaves of Ipomoea carnea. International Journal of PharmTech Research 1(4): 1224-1226.

28. Saleem M, Touseef MI, Riaz N, Jabbar A, Hafeez M, et al. (2011) Phytochemicals from Ipomoea carnea collected from Murree hills. Journal of the Chemical Society of Pakistan 33(5): 747-750.

29. Smita J, Patil UK (2014) Effect of Ipomea carnea Jacq. flowers on hematological changes in toluene diisocyanate-induced inflammation in Wistar rats. Chin J Nat Med 12(3): 161-166.

30. Patel AK, Oosterwijk NV, Singh VK, Rozeboom HJ, Kalk KH, et al. (2009) Crystallization and preliminary X-ray analysis of carnein, a serine protease from Ipomoea carnea. Acta Crystallogr Sect F Struct Biol Cryst Commun 65(4): 383-385.

31. Bhalerao SA, Teli NC (2016) Ipomoea carnea Jacq.: Ethnobotany, phytochemistry and pharmacological potential. International Journal of Current Research in Biosciences and Plant Biology 3(8): 138-144.

32. Phillips O, Gentry AH, Reynal L, Wilkin P, Gulvez DCB (1994) Quantitative ethnobotany and Amazonian conservation. Conservation Biology 8(1): 225-248.

33. Ijeoma UF, Aderonke SO, Ogbonna O, Augustina MA, Ifeyinwa CN (2011). Antinociceptive and anti-inflammatory activities of crude extracts of Ipomoea involucrata leave in mice and rats. Asian Pacific Journal of Tropical Medicine 4(2): 121-124.

34. Khalid MS, Singh RK, Reddy IVN, Kumar SJ, Kumar BS, et al. (2011) Anti-inflammatory activity of aqueous extract of Ipomoea carnea Jacq Pharmacology Online 1: 326-331.

35. Abbasi MA, Zafar A, Riaz T, Rehman A, Arshad S, et al. (2010) Evaluation of comparative antioxidant potential of aqueous and organic fractions of Ipomoea carnea. Journal of Medicinal Plants Research 4(18): 18831887.

36. Adsul VB, Khatiwora E, Deshpande NR (2012) Evaluation of antioxidant activity of Ipomoea carnea leaves. Journal of Natural Products and Plant Resources 2(5): 584-588.

37. Kadiyawala ALA, Prasad AK, Kumar S, Iyer SV, Patel HA, et al. (2012) Comparative anti-diabetic studies of leaves of Ipomoea carnea and Grewia asiatica on streptozotocin induced diabetic rats. International Journal of Pharmaceutical \& Biological Archives 3(4): 853-857.

38. Kumar A, Manral U, Sharma S (2014) Traditional remedy for muscle strain using Ipomoea carnea Jacq. and Ricinus communis L. leaves in Haryana, India. International Journal of Medicinal Plants (Photon) 108: 625-631.
39. Adsul VB, Khatiwora E, Torane R, Deshpande NR (2012) Antimicrobial activities of Ipomoea carnea leaves. Journal of Natural Products and Plant Resources 2(5): 597-600.

40. Nidiry ES, Ganeshan G, Lokesha AN (2011) Antifungal activity and isomerization of octadecyl p-coumarates from Ipomoea carnea subsp. fistulosa. Nat Prod Commun 6(12): 1889-1892.

41. Bachhav KV, Burande MD, Rangari VD, Mehta JK (1999) Effect of aqueous extract of Ipomoea carnea leaf on isolated frog and mouse heart. Indian J Exp Biol 37(11): 1080-1084.

42. Hueza IM, Fonseca ESM, Paulino CA, Haraguchi M, Gorniak SL (2003). Evaluation of immunomodulatory activity of Ipomoea carnea on peritoneal cells of rats. J Ethnopharmacol 87 (2): 181-186.

43. Bidkar JS, Bhujbal MD, Ghanwat DD, Dama GY (2012) Anxiolytic activity of aqueous and methanolic extracts of Ipomoea carnea leaves. International Journal of Universal Pharmacy and Bio Sciences 1(2): $1-11$.

44.Gupta RKR, Chaudhary S, Vaishali A, Singh RKR (2012) Antihepatotoxic influence of aqueous extract of Ipomoea carnea against carbon tetrachloride induced acute liver toxicity in experimental rodents. Asian Journal of Pharmaceutical and Clinical Research 5(4): 262-265.

45. Ambiga S, Narayanan R, Gowri D, Sukumar D, Madhavan S (2007) Evaluation of wound healing activity of flavonoids from Ipomoea carnea Jacq. Anc Sci Life 3: 45-51.

46. Rout SK, Kar DM (2015) Antimicrobial, antioxidant and wound healing activity of the crude extract and different fractions of methanolic extract of Ipomoea carnea. Der Pharmacia Lettre 7(5): 1-9.

47. Panda V, Sonkamble M, Patil S (2011) Wound healing activity of Ipomoea batatas tubers (sweet potato). Functional Foods in Health and Disease 10: 403-415.

48. Sharma A, Bachheti RK (2013) A review on Ipomoea carnea. International Journal of Pharma and Bio Sciences 4(4): 363-377.

49. Amna AA, Abdelgadir EH, Adam SEI (2011) Toxic Effect of Ipomoea carnea leaves on Wistar Rats. Journal of Pharmacology and Toxicology 6(1): 18-23.

50. Rios E, Cholich L, Silva J, Acosta de Perez O (2008) Histopathological lesions in central nervous system of goats poisoned by Ipomoea carnea. Revista Veterinaria 19(2): 130-134.

51. Barbosa RC, Riet CF, Medeiros RM, Lima EF, Barros SS, et al. (2006) Intoxication by Ipomoea sericophylla and Ipomoea riedelii in goats in the state of Paraiba, Northeastern Brazil. Toxicon 47(4): 371-379.

52. Schwarz A, Gorniak SL, Bernardi MM, Dagli MLZ, Spinosa HS (2003) Effects of Ipomoea carnea aqueous fraction intake by dams during pregnancy on the physical and neurobehavioral development of rat offspring. Neurotoxicol Teratol 25(5): 615-626.

53. Hosomi RZ, Spinosa DSH, Gorniak SL, Habr SF, Penteado SW, et al (2008) Embryotoxic effects of prenatal treatment with Ipomoea carnea aqueous fraction in rats. Braz j vet res anim Sci 45(1): 67-75.

54. Hueza IM, Guerra JL, Haraguchi M, Naoki A, Gorniak SL (2005) The role of alkaloids in Ipomoea carnea toxicosis: a study in rats. Exp Toxicol Pathol 57(1): 53-58.

55. Pipole F, Latorre AO, Hueza IM (2010) Ipomoea carnea, a poisonous plant, promotes changes in lymphocyte distribution of young rats. Toxicology Letters 196(17): 200-204.

56. Cholich LA, Márquez M, Batlle MP, Gimeno EJ, Teibler GP, et al. (2013) Experimental intoxication of guinea pigs with Ipomoea carnea Behavioural and neuropathological alterations. Toxicon 76: 28-36. 
57. Garcia EN, Aguirre MV, Gimeno EJ, Rios EE, Acosta OC, et al. (2015) Haematologic alterations caused by Ipomoea carnea in experimental poisoning of guinea pig. Exp Toxicol Pathol 67(10): 483-490.
58. Gotardo AT, Pavanelli EL, Carvalho HF, Lemes KM, Arruda RP, et al. (2014) Endocrine disrupter action in ruminants: A study of the effects of Ipomoea carnea in adult male goats. Small Ruminant Research 119(3): 81-87.

\section{Your next submission with Juniper Publishers will reach you the below assets}

- Quality Editorial service

- Swift Peer Review

- Reprints availability

- E-prints Service

- Manuscript Podcast for convenient understanding

- Global attainment for your research

- Manuscript accessibility in different formats ( Pdf, E-pub, Full Text, Audio)

- Unceasing customer service

Track the below URL for one-step submission https://juniperpublishers.com/online-submission.php 